整化 第 37 巻，第 6 号, p. $367 \sim 369,1963]$

\title{
ガスクロマトグラフィーによる乳剈中の クロルベンジレートの定量*
}

金 沢 純, 佐藤六 郎 (濃林省膿薬検查所)

昭和 38 年 1 月 28 日受理

クロルベンジレート (ethyl $p, p^{\prime}$-dichlorobenzilate) はガイギー社で創製された殺ダニ剤で，わが国でも果樹 類の葉ダニの防除に近年多量に使用されている.

著者らはクロルベンジレートの製剤に特異的な分析法を見いだす目的からこの研究を行なった。クロルベンジ レートの定量法には従来，全塩菜法(1)，酸化法(2)，硝化法(3)などが知られている。これらの方法のうち，全塩素 法恃他の塩素化合物の影響を受け，特異性にとぼしく，京た酸化法特よび硝化法は元来，作物体に物ける残留物 の分析を目的とした方法であるので，感度はすぐれているが，精度特よび正確さの点から製剂の分析法としては 不適当と考兄られる. クロルベンジレートのガスクロマトグラフィーについては Burke ら ${ }^{(4)}$ が他の塩素系殺虫 剤とともに保持容量を示し，測定の可能性を示唆しているのみで，未だ本法による製剤の分析法は検討されてい ない，そこで著者らは諸々定量条件を検討したところ，乳剤分析法としてほ㳯満足すべき方法を設定することが できたので，以下に報告する。

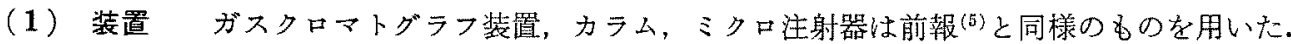

(2) 試薬 クロルベンジレート純品は日本化薬製の m. p. 37〜38 のものを, ジオクチルフタレート(DOP) は1 級試薬を用いた。これらの純度を使用前に以下記した条件でガスクロマトグラフィーにかけ，ガスクロマ

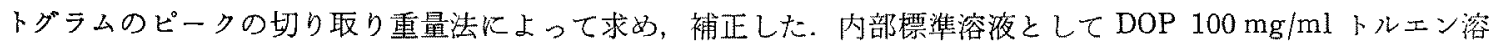
液を調製し，使用した。

（3）カラム充てん物高真空用シリコングリース（Dow Corning）を酢酸エチルで溶解してセライト 545 (32〜48 メッシュ) に 5 重量\%担持させたものを用いた。

（4）測定条件 カラム温度は $215^{\circ}$ としキャリサーガスはへリウムを用い，流速は $73 \mathrm{ml} / \mathrm{min}$ とした。 検出器のフィラメント電流は $180 \mathrm{~mA}$ K, 感度は $8 \mathrm{mV}$ に調整し，チャート速度は $1 \mathrm{~cm} / \mathrm{min}$ で測定した，

（5）検量線の作成クロルベンジレート純品 100，200，300，400，500 mg t50 ml の三角フラスコに はかりとり，なるべく少量のトルェンで溶解し，これ炕 DOP 内部標集溶液 $2 \mathrm{ml}$ (DOP $200 \mathrm{mg}$ を含を) を正 確に加えよく混合する。これより $20 \mu \mathrm{l}$ をミクロ注射器でとり，(4)化記した測定条件でガスクロマトグラムを 記録し，ピーク面積を半值幅法（半值幅×高さ）で測定する，そして重量比（クロルベンジレート/DOP）を綎軸 に，ピーク面積比を横軸にとり，検量線を作因する。

（5）乳剤の分析法 クロルベンジレート $300 \mathrm{mg}$ を含さ試料を $50 \mathrm{ml}$ の三角フラスコにはかりとりこ れに DOP 内部標準溶液 $2 \mathrm{ml}$ を正確に加え, 上く混合する.これより $20 \mu 1$ をミクロ注射器でとり, 検量線を 作成したときと同様の条件でガスクロマトグラムを測定し，検量線によりピーク面積比を重量比に換算し，試料 中のクロルベンジレートの重量\%を算出する。

\section{結果および考察}

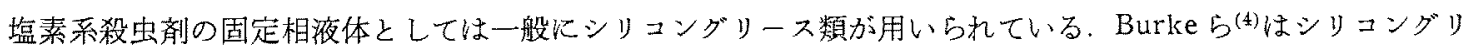
一ス: Chromosorb (2:8) のカラムを用い, クロルベンジレートを含む71 種の塩素系農薬の相対保持容量（ア ルドリン=1）を示した．著者らも2，3の高温がスクロマトグラフィー用の固定相液体を検討したが，高真空用

* Determination of Chlorobenzilate in Emulsifiable Concentrates by Gas-Liquid Chromatography. By Jun KANAZAwa and Rokuro SATo (Agricultural Chemicals Inspection Station, Ministry of Agriculture and Forestry)

農薬のガスクロマトグラフィー(第10 報). 
第 1 表 保 持容 量*

\begin{tabular}{|c|c|c|}
\hline 化 合 物 & $\begin{array}{c}\text { 保持容量 } \\
(\mathrm{m} 1)\end{array}$ & $\begin{array}{l}\text { 相站保持容置 } \\
(\mathrm{DOP}=1.00)\end{array}$ \\
\hline chlorobenzilate & 161 & 0.48 \\
\hline $\mathrm{DMC}^{* *}$ & 102 & 0.30 \\
\hline$p, p^{\prime}-\mathrm{DDT}$ & 219 & 0.65 \\
\hline$o, p^{\prime}-\mathrm{DDT}$ & 193 & 0.57 \\
\hline DOP & 336 & 1.00 \\
\hline 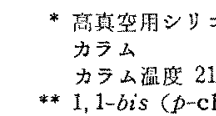 & ophen & $\begin{array}{l}3 \mathrm{ml} / \mathrm{m} \\
\text { anol }\end{array}$ \\
\hline
\end{tabular}

シリコングリースが最良であった，固定相 液体の担体に対する担持割合はピークの形 状や分析時間などから考元，5\% 位が適当 と思加れた。

(4) の湘定条件に持けるクロルペンジレ 一ト和よび類縁殺虫剂の保持容量を第 1 表 に示した：このカラム条件ではクロルベン ジートと 1,1-bis (p-chlorophenyl) ethanol (DMC) 托よびo, $p^{\prime}$-DDTとの分離は 不完全であった。 しかしクロルペジレー

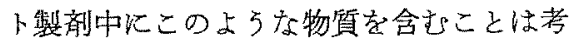
えら机ず，また現在これら殺蛳との混合 製剤当見ら机ないのて，このカラム条件で 定量法の検討学進めた。

内部標準物質としてはクロルペンジレー トのピークよりも前に溶出するジブチルフ

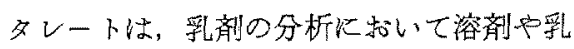
化剂の影響を受け，不適当であった。一力 DOP は夕ロルベンジレートのピークより 多後に溶出するのでこの影謷がみらられなか った。 DOP 学内部標準物筫として作成し た㭘量線は，第1图に示したように重量比 (クロルベンジレート/DOP) $0.5 \sim 2.50$ 範 用でほ偣原点を通る直線が克られ，この検 量線の傾斜は 1.1515 でった。したがっ て，この椧量線の傾斜をピーク面積比から 重量比に換算する係数として採用すること がてさる。

この検量線学用いてクロルベンジレート の工策用原体を分析した昜合の 1 例を第 2 表に示した：この結果は分析值の変動が少

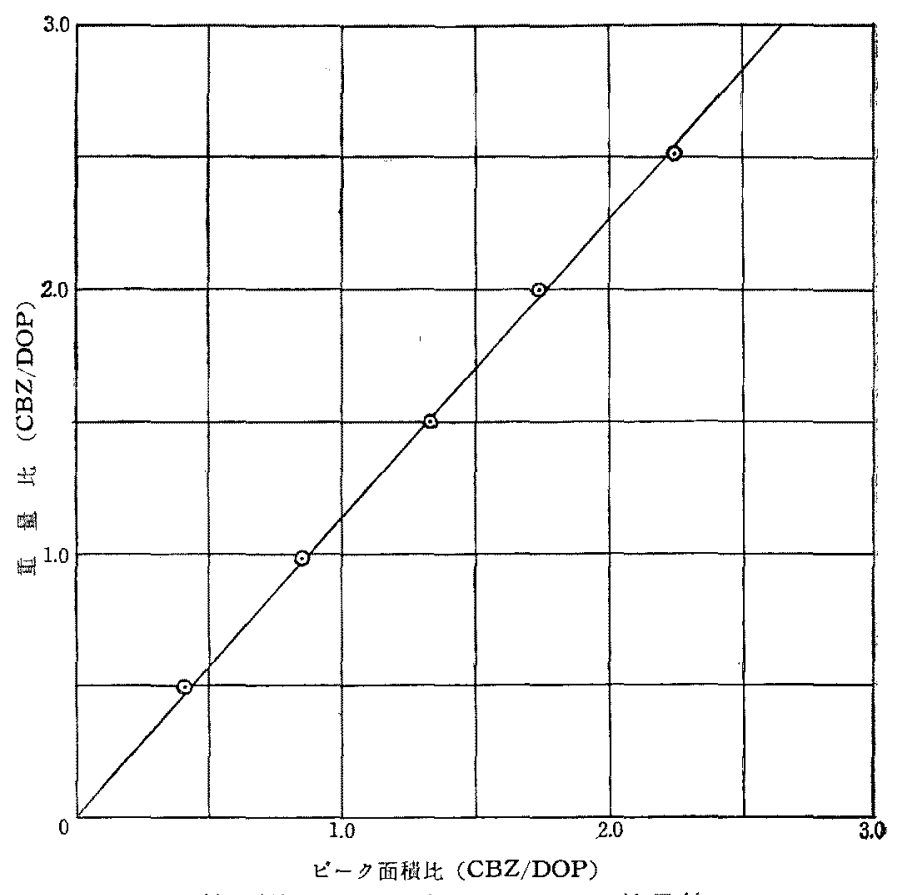

第1図クロルヘンシシレートの検量楾

符 2 表 タロルペンジレート工業用原体の分析結果

\begin{tabular}{|c|c|c|c|c|c|}
\hline No. & 試料量 & DOP 架 & $\begin{array}{l}ヒ ゚ ー ク \text { 面積比 } \\
\text { クロルベンシ }\end{array}$ & \multicolumn{2}{|c|}{ 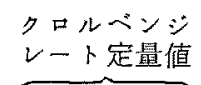 } \\
\hline & (g) & $(g)$ & r (DOP) & (g) & $(\%)$ \\
\hline 1 & 0.3311 & 0.2953 & 0.9137 & 0.3107 & 93.8 \\
\hline 2 & 0.4968 & " & 1. 3731 & 0. 4669 & 94.0 \\
\hline 3 & 0. 4692 & $" \prime$ & 1. 2939 & 0.4400 & 93.8 \\
\hline 4 & 0.5735 & $" \prime$ & 1. 5834 & 0.5384 & 93.9 \\
\hline & & & & 平均 & 93.9 \\
\hline
\end{tabular}

第 3 表 タロルベンジレート調留乳剂* の分析結果

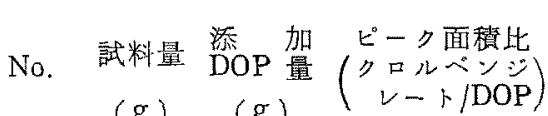

(g)

( $\mathrm{g}$ )

$\begin{array}{lll}1 & 1.2483 & 0.1969 \\ 2 & 1.2702 & \\ 3 & 1.1845 & \\ 4 & 1.1858 & \\ 5 & 1.2155 & \\ 6 & 1.5025 & \\ 7 & 1.0402 & \end{array}$

\section{2157}

1. 2730

1. 1570

1. 1420

1. 1794

1. 4836

1. 0086

*クロルベンジレート計算俌 $22.38 \%$
クロルベンシ

レート定量值

(g) $(\%)$ 回収率

$0.2756 \quad 22.1$

$0.2886 \quad 22.7 \quad 1015$

$\begin{array}{lll}0.2623 & 22.1 & 98.9\end{array}$

$\begin{array}{lll}0.2589 & 21.8 & 97.5\end{array}$

$\begin{array}{lll}0.2674 & 22.0 & 98.3\end{array}$

$\begin{array}{lll}0.2288 & 22.0 & 98.2\end{array}$

平 均 22.299 .0

標垁偏差 0.30

变動係数 1.36 $\begin{array}{lll}0.3364 & 22.4 & 100.0\end{array}$ なく，本法が工業用原体の純监分析に有用ですることを示している。

つぎに本法の正確さおよび精度を明らがするため，第 2 表で純度分析した工業用原体を用いて，含有量既知 のクロルヘンジレート乳剂を調製し，同一調製試料を繰り返し分析した結果を第 3 奉に，このとさにえられたガ スクロマトグラムの1例を第 2 図に示した。またこの調製乳剂て同一試料分析時の面積比の变動を調査した結果 を第 4 表に示した，第 3 表に示さ狆るよ 3 に本法の精度は標準偏差で $0.30 \%$ でり，計算值に対する平均回收 


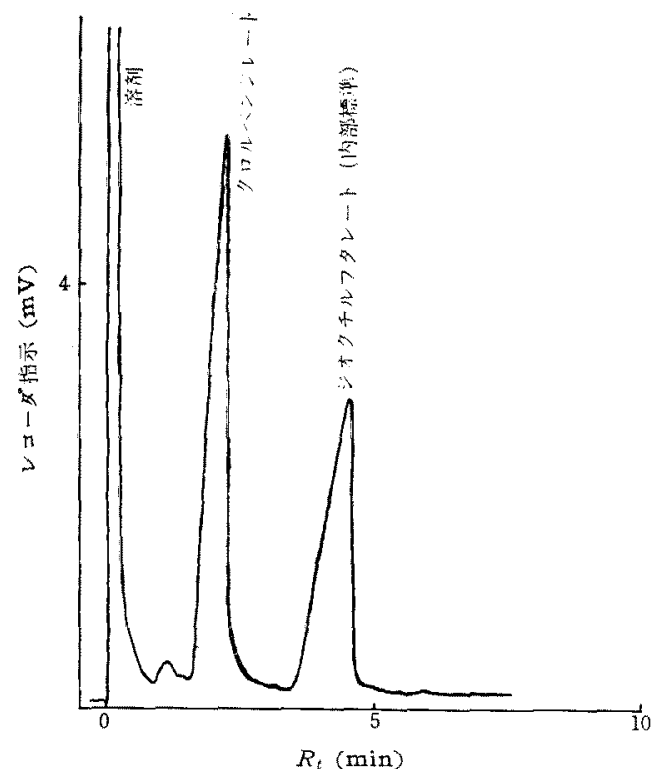

第2因クロルベンジレート乳剤のガスクロマト グラム

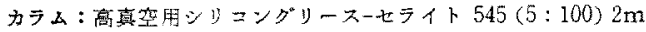

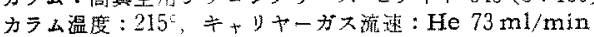

（1）農林省告示第 718 号：膿薬公定检查法(3), 2 (1956).

(2) R.C. Blinn, F.A. Gunther, M. J. Kolbezen: J. Agr. Food Chem., 2, 1080 (1954).
第 4 表 同一陚料分析時の面筫比の变動

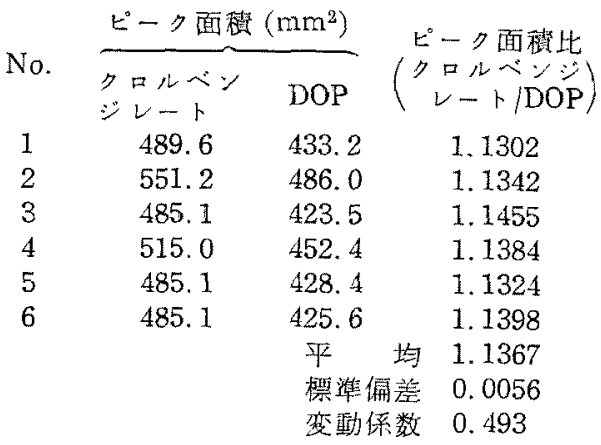

率は 99.0\% を示し，クロルペンジレート乳剂の品質 管理分析法として满足すべきのと思秃尚。

分析所要時間はダスクロマトグラフ装置の調整持間 を除け湔30 分で女る。

(3) H. J. Harris : ibid., 3, 939 (1955).

(4) J. Burke, L. Johnson : J. Assoc. Offic. Agr. Chemists, 45, 348 (1962).

（5）金沢 純, 佐蕌六郎： 本誌, 37,306(1963). 